\title{
Genetic Variability and Divergence Studies for Seed Yield and Component Characters in Indian Mustard [Brassica juncea (l.) Czern. \& coss.] Over Environments
}

\author{
Arpna Kumari* and Vedna Kumari
}

\author{
Department of Crop Improvement \\ CSK Himachal Pradesh Krishi Vishvavidyalaya, Palampur-176062, India
}

*Corresponding author

\section{Keywords \\ Brassica juncea, Indian mustard, genetic variability, genetic divergence, cluster analysis}

Article Info

Accepted:

24 June 2018

Available Online:

10 July 2018

\section{A B S T R A C T}

Genetic variability and diversity play a major role in framing successful breeding programme. It is evident that genetically diverse parents are likely to produce high heterotic effects and yield desirable transgressive segregants. Keeping this in view, the present study was conducted to evaluate nature and extent of genetic variability and diversity in Indian mustard [Brassica juncea (L.) Czern. \& Coss.]. About 31 genotypes including local, indigenous and exotic germplasm lines were evaluated in randomized complete block design with three replications across two environments during rabi 2008-09 and 2009-10. Significant variations across the years were observed. The results were also substantiated by the pooled analysis of variance that revealed highly significant differences for genotypes, environments and their interactions for most of the characters. Phenotypic coefficient of variation was higher than genotypic coefficient of variation for all the observed characters. High PCV and GCV were recorded for NAR and CGR. Genetic contribution of phenotypic expression of a trait is better reflected by the estimates of heritability. In this study, high heritability was recorded for biological yield per plant and seed yield per plant. Genetic advance expressed as per cent of mean was higher for NAR, CGR, biological yield per plant, harvest index and seed yield per plant. High heritability coupled with high genetic advance was observed for seed yield per plant and biological yield per plant indicating the role of effective selection to get genetic gain. Cluster analysis grouped the genotypes into six clusters and exhibited the presence of substantial genetic diversity among the genotypes. Cluster I was largest consisting of 26 genotypes while remaining clusters comprised of only one genotype each. The intra-cluster distance was comparable for cluster I (1.22) while for clusters II, III, IV, V and VI, intra-cluster distances were zero. The highest inter-cluster distance was observed between clusters III and V (3.41) followed by distance between clusters V and VI (3.36) and clusters II and V (3.14). The crosses involving parents belonging to most divergent clusters are expected to manifest maximum heterosis. Thus, crosses between the genotype of cluster III (Geeta) with that of cluster V (Heera) would produce high heterosis and are also likely to exhibit new recombination with desired traits in Indian mustard. The study revealed that cluster analysis for Indian mustard genotypes using growth parameters, morphological and yield contributing characters provides greater confidence for assessment of genetic diversity which could be used in subsequent breeding programme. 


\section{Introduction}

Oilseeds occupy an important position in Indian agricultural economy and daily diet, being a rich source of fats and vitamins. Among oilseeds, rapeseed-mustard is the third important oilseed crop in the world after soybean (Glycine max) and palm (Elaeis guineensis Jacq.) oil. Among the seven edible oilseed cultivated in India, rapeseed-mustard (Brassica spp.) contributes $28.6 \%$ in the total production of oilseeds. In India, it is the second most important edible oilseed after groundnut sharing $27.8 \%$ in the India's oilseed economy. The share of oilseeds is $14.1 \%$ out of the total cropped area in India, rapeseedmustard accounts for 3\% of it (Shekhawat et al., 2012). The global production of rapeseedmustard and its oil is around 38-42 and 12-14 million tonnes, respectively. India contributes $28.3 \%$ and $19.8 \%$ in world acreage and production. India produces around 6.7 million tonnes of rapeseed-mustard next to China (1112 million tonnes) and EU (10-13 million tonnes) with significant contribution in world rapeseed-mustard industry (USDA, 2016). The rapeseed-mustard group broadly includes Indian mustard, yellow sarson, brown sarson, raya, and toria crops. Among rapeseedmustard group, Indian mustard is one of the most important oilseed crop contributing about $80 \%$ of the total rapeseed-mustard which is one of the major oilseed crops cultivated in India. It is predominantly cultivated in Rajasthan, UP, Haryana, Madhya Pradesh, Himachal Pradesh, and Gujarat. It is also grown under some non-traditional areas of South India including Karnataka, Tamil Nadu, and Andhra Pradesh. Brown mustard (Brassica juncea L. Czern.) is one of the three oilseed Brassica species. As it is the case in India and China, the brown mustard is used for oil production which involved breeding varieties with low glucosinolates and low erucic acid levels in grains (Othmane, 2015). But there is a wide fluctuation in area, production and productivity of this crop. This fluctuation is mainly due to lack of high yielding genotypes with stable performance over the environments, cultivation on marginal lands either rain fed or with limited irrigation facilities and non-availability of biotic and abiotic stress-resistant/tolerant varieties for different mustard growing regions of the country.

The success of any breeding programme in general, and improvement of specific trait through selection in particular, depends upon the genetic variability present in the available germplasm of a particular crop. For the success of the crop improvement programme, the characters for which variability is present, should be highly heritable as progress due to selection depends on heritability, selection intensity and genetic advance of the character. Heritability and genetic advance estimates for different targeted traits help the breeder to apply appropriate breeding methodology in the crop improvement programme. In hybridization programme where selection of genetically diverse parents is important to get wide array of recombinants, the clear understanding of genetic diversity among the entries of germplasm is necessary. In order to assess the diversity in accessions, cluster analysis is found to be useful tool for classification of genotypes into homogenous groups. The present study was conducted to evaluate the nature and extent of genetic variability and diversity among 31 Indian mustard genotypes for different growth parameters, morphological and yield contributing characters.

\section{Materials and Methods}

The materials for the present investigation comprised of 31 genotypes obtained from local, indigenous and exotic sources (Table 1). All the genotypes were evaluated in respect of seven growth parameters and fifteen 
morphological and yield contributing characters during the two rabi seasons viz., 2008-09 and 2009-10 at the experimental farm of the Department of Crop Improvement, CSK HPKV, Palampur. The more information on locations and climatic conditions are given in Table 2. The experiment was laid out in randomized complete block design in three replications with the plot size of $3.0 \times 0.9 \mathrm{~m}^{2}$ on $20^{\text {th }}$ October, 2008. During rabi 2009-10, the experiment was conducted again in randomized complete block design in three replications with the plot size of $2.5 \times 0.9 \mathrm{~m}^{2}$ on $26^{\text {th }}$ October, 2009. The row - row and plant - plant spacings during both seasons were kept 30 and $10 \mathrm{~cm}$, respectively. Each genotype was raised in three rows. The recommended cultural practices were followed to raise the crop under irrigated conditions. For growth parameters viz., Crop Growth Rate (CGR), Relative Growth Rate (RGR), Net Assimilation Rate (NAR), Leaf Area Ratio (LAR), Leaf Area Index (LAI), Leaf Area Duration (LAD) and Specific Leaf Weight (SLW), the observations were recorded on the basis of three randomly competitive plants in each plot. During both seasons, data were recorded at an interval of 45-60 days after sowing, these intervals have been treated as individual stage. For morphological characters such as plant height, number of primary branches per plant, number of secondary branches per plant, siliquae per plant, length of main shoot, siliquae on main shoot, siliqua length, seeds per siliqua, 1000-seed weight, seed yield per plant, biological yield per plant and harvest index, the observations were recorded on five randomly selected plants from each genotype in each replication. The observations on days to flower initiation, days to 50 per cent flowering and days to 75 per cent maturity were recorded on plot basis.

The analysis of variance for different characters was carried out using the mean data in order to partition variability due to different sources by following Panse and Sukhatme (1985). The combined analysis of variance over the environments was computed as per the procedure given by Verma et al., (1987). In order to assess and quantify the genetic variability among the genotypes for the characters under study, the phenotypic coefficient of variation (PCV), genotypic coefficient of variation (GCV), heritability and genetic advance were estimated following standard statistical procedures (Burton and De Vane, 1953 and Johnson et al., 1955). The genetic divergence among genotypes was computed by means of Mahalanobis $\mathrm{D}^{2}$ technique (1936). The difference between the genotypes for the set of characters was tested and the genotypes were grouped into clusters following Tocher's method (Rao, 1952). The contribution of characters towards divergence was estimated using canonical analysis.

\section{Results and Discussion}

The analysis of variance of mean values for characters revealed that mean squares were highly significant for days to flower initiation, days to 50 per cent flowering plant height, number of secondary branches per plant, 1000-seed weight, seed yield per plant, biological yield per plant and harvest index in both environments. Similar observations were reported earlier in Indian mustard (Verma et al., 2008, Singh et al., 2010 and Yadava et al., 2011). The reason for high magnitude of variability in the present study may be due the fact that the genotypes selected were developed in different breeding programmes representing different agro-climatic conditions of the country. The estimates of PCV were higher than their corresponding GCV for all characters studied which indicated that the apparent variation is not only due to genotypes but, also due to the influence of environment (Table 3). Therefore, caution has to be exercised in making selection for these characters on the basis of phenotype alone as 
environmental variation is unpredictable in nature. Similar findings with respect to PCV and GCV have been reported by earlier workers (Mahla et al., 2003, Mahak et al., 2004, Satyendra and Mishra, 2007 and Yadava et al., 2011, Chandra et al., 2018). Based on the pooled data, high PCV and GCV were observed for NAR and CGR. Moderate estimates of PCV and GCV were recorded for biological yield per plant, LAR, harvest index, seed yield per plant, 1000-seed weight, number of secondary branches per plant and seeds per siliqua while low for days to flower initiation, days to 50 per cent flowering and days to 75 per cent maturity. The values were extremely low for RGR. These results were well supported by similar findings by Kumar et al., (2007). Singh et al., (2011) and Kumar et al., (2013) reported moderate values for PCV and GCV for the number of secondary branches per plant and for seed yield per plant.

Genetic contribution to phenotypic expression of a trait is better reflected by the estimates of heritability. A higher estimate of heritability indicates presence of more fixable variability. In this study, high heritability $\left(\mathrm{h}_{\mathrm{bs}}^{2}\right)$ estimates were recorded for biological yield per plant and seed yield per plant. For seed yield per plant and other characters, earlier workers have also reported high heritability (Mahla et al., 2003 and Satyendra and Mishra, 2007) which indicated that better expressions of these traits are primarily due to the genetic factors and hence, fixable. Genetic advance expressed as per cent of mean was higher for NAR, CGR, biological yield per plant, harvest index and seed yield per plant. Similar findings related to high genetic advance expressed as per cent of mean have been reported by earlier workers for various traits (Mahla et al., 2003, Satyendra and Mishra, 2007 and Singh et al., 2011). Prediction of successful selection becomes more accurate if it is based on estimates of heritability coupled with high genetic advance, because it gives estimates not only of genetic contribution but, of expected genetic gain out of selection as well. In this study, high heritability coupled with high genetic advance was observed for biological yield per plant and seed yield per plant. The results suggested the importance of additive gene action for their inheritance and improvement could be brought about by phenotypic selection. High heritability coupled with high genetic advance for seed yield per plant has also been observed (Mahla et al., 2003, Satyendra and Mishra, 2007) which supports the results of present investigation. Lodhi et al., (2014) and Synrem et al., (2014) reported high heritability in conjunction with high genetic advance were observed for seed yield/ plant, number of secondary branches/ plant, 1000-seed weight, and biological yield per plant suggesting predominant role of additive gene action for expression of these traits.

The technique of multivariate analysis was used for grouping of genotypes into clusters. Test of significance based on Wilk's criterion obtained for each pair of populations were observed to be significant in pooled over the environments. Cluster analysis delineated 31 genotypes into six clusters (Table 4 and Figure 1). Cluster I was largest consisting of 26 genotypes while remaining clusters comprised of only one genotype each suggesting that genotypes such as OMK-1, Geeta, 03-456, Heera and HPMM-03-108 appeared to be most divergent from others. The composition of clusters revealed that genotypes of a cluster originate from wide range of eco-geographical areas, thereby suggested that genetic differences and similarities among the genotypes were irrespective of the areas. This allows us to select parents for hybridization on the basis of genetic diversity and not merely on the basis of eco-geographical isolation. Tahira et al., 2013 and Gohel and Mehta, 2014 have also observed the similar results. 
Table.1 List of Brassica genotypes and their source used in the study

\begin{tabular}{|c|c|c|}
\hline Sr. No. & Genotype & Source \\
\hline 1 & Vardan & Kanpur \\
\hline 2 & $03-218$ & H.P. \\
\hline 3 & HPMM-03-108 & H.P. \\
\hline 4 & $03-143$ & H.P. \\
\hline 5 & RCC-4 & H.P. \\
\hline 6 & OMK-2 & H.P. \\
\hline 7 & NRC-1 & Rajasthan \\
\hline 8 & NRC-2 & Rajasthan \\
\hline 9 & NRC-17 & Rajasthan \\
\hline 10 & PusaJaikisan & New Delhi \\
\hline 11 & $03-456$ & H.P. \\
\hline 12 & Heera & Exotic \\
\hline 13 & RL-1359 & Ludhiana \\
\hline 14 & OMK-5-1 & H.P. \\
\hline 15 & OMK-1 & H.P. \\
\hline 16 & OMK-2-21 & H.P. \\
\hline 17 & OMK-3 & H.P. \\
\hline 18 & OMK-3-29 & H.P. \\
\hline 19 & IC-355309 & NBPGR, New Delhi \\
\hline 20 & IC-355331 & NBPGR, New Delhi \\
\hline 21 & IC-355337 & NBPGR, New Delhi \\
\hline 22 & Geeta & Haryana \\
\hline 23 & IC-355421 & NBPGR, New Delhi \\
\hline 24 & Bawal-151 & Haryana \\
\hline 25 & Varuna & Kanpur \\
\hline 26 & OMK-5-2 & H.P. \\
\hline 27 & RH-8544 & Hisar \\
\hline 28 & Nav Gold & Rajasthan \\
\hline 29 & OMK-5-3 & H.P. \\
\hline 30 & OMK-5-4 & H.P. \\
\hline 31 & Zem-1 & Exotic \\
\hline
\end{tabular}


Table.2 Descriptions of environments where trials were conducted during 2008-10

\begin{tabular}{|c|c|c|c|c|c|c|c|c|}
\hline \multirow[t]{2}{*}{ Location } & \multirow[t]{2}{*}{$\begin{array}{l}\text { Cropping } \\
\text { season }\end{array}$} & \multirow[t]{2}{*}{ Month } & \multicolumn{2}{|c|}{$\begin{array}{l}\text { Temperature } \\
\left({ }^{0} \mathrm{C}\right)\end{array}$} & \multirow[t]{2}{*}{$\begin{array}{c}\text { Rainfall } \\
\text { (mm) }\end{array}$} & \multirow{2}{*}{$\begin{array}{c}\text { Relative } \\
\text { Humidity } \\
(\%)\end{array}$} & \multirow{2}{*}{$\begin{array}{l}\text { Rainy } \\
\text { Days } \\
\text { (No.) }\end{array}$} & \multirow[t]{2}{*}{$\begin{array}{l}\text { Solar radiation } \\
\left(\mathrm{MJ} \mathrm{m}^{2}{ }^{\text {day- }}{ }^{1}\right)\end{array}$} \\
\hline & & & Max & Min & & & & \\
\hline \multirow{7}{*}{$\begin{array}{l}\text { Palampur } \\
\text { (E-I) }\end{array}$} & \multirow{7}{*}{$\begin{array}{c}r a b i \\
(2008-09)\end{array}$} & Oct. & 25.2 & 13.1 & 65.4 & 73 & 5 & 8.0 \\
\hline & & Nov. & 22.2 & 8.6 & 0.0 & 60 & 0 & 9.0 \\
\hline & & Dec. & 20.5 & 7.6 & 9.2 & 58 & 2 & 7.5 \\
\hline & & Jan. & 17.5 & 6.5 & 56.4 & 72 & 9 & 5.3 \\
\hline & & Feb. & 19.0 & 7.5 & 32.0 & 66 & 5 & 7.0 \\
\hline & & March & 22.7 & 10.3 & 89.2 & 58 & 5 & 6.2 \\
\hline & & April & 26.4 & 13.8 & 65.0 & 55 & 6 & 8.1 \\
\hline \multirow{7}{*}{$\begin{array}{l}\text { Palampur } \\
\text { (E-II) }\end{array}$} & \multirow{7}{*}{$\begin{array}{c}\text { rabi } \\
(2009-10)\end{array}$} & Oct. & 25.6 & 11.6 & 33.9 & 80.48 & 4 & 9.3 \\
\hline & & Nov. & 20.8 & 7.6 & 69.4 & 81.54 & 5 & 7.1 \\
\hline & & Dec. & 18.0 & 5.2 & 0.0 & 75.54 & 0 & 5.8 \\
\hline & & Jan. & 18.3 & 4.9 & 25.2 & 76.49 & 2 & 7.1 \\
\hline & & Feb. & 18.3 & 6.2 & 120.6 & 82.66 & 6 & 6.2 \\
\hline & & March & 25.6 & 12.4 & 26.0 & 61.40 & 3 & 8.1 \\
\hline & & April & 30.3 & 15.7 & 27.9 & 48.30 & 5 & 8.1 \\
\hline
\end{tabular}

Figure.1 Dendrogram showing grouping of 31 Brassica juncea genotypes generated using D ${ }^{2}$ cluster analysis (Tocher's method) in pooled over the environments

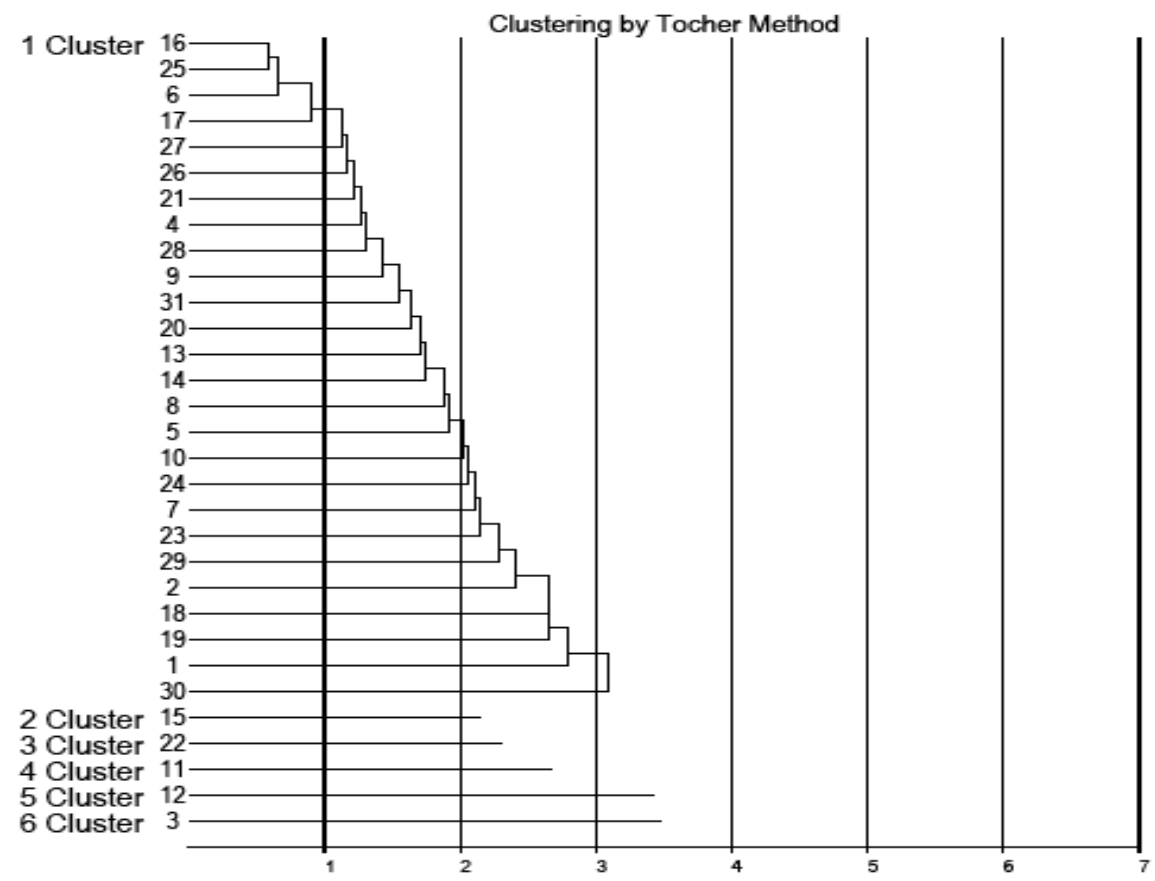


Table.3 Estimates of different parameters of variability for various characters in pooled over the environments

\begin{tabular}{|l|l|l|l|l|}
\hline Characters & $\begin{array}{l}\text { PCV } \\
(\%)\end{array}$ & $\begin{array}{l}\text { GCV } \\
(\%)\end{array}$ & $\begin{array}{l}\mathrm{h}^{2} \text { bs } \\
(\%)\end{array}$ & $\begin{array}{l}\text { Genetic advance } \\
(\%) \text { of mean }\end{array}$ \\
\hline CGR & 50.00 & 30.35 & 36.85 & 37.95 \\
\hline RGR & 0.00 & 0.00 & 0.00 & 0.00 \\
\hline NAR & 50.77 & 32.10 & 39.97 & 41.78 \\
\hline LAR & 27.93 & 12.04 & 18.52 & 10.66 \\
\hline LAI & 38.72 & 15.10 & 15.20 & 12.12 \\
\hline LAD & 38.59 & 16.19 & 17.61 & 14.00 \\
\hline SLW & 41.31 & 17.15 & 17.24 & 14.67 \\
\hline Days to flower initiation & 6.90 & 5.29 & 58.86 & 8.37 \\
\hline Days to 50 \% flowering & 5.84 & 4.20 & 51.70 & 6.22 \\
\hline Days to 75 \% maturity & 1.50 & 0.83 & 30.76 & 0.95 \\
\hline Plant height (cm) & 12.89 & 8.65 & 45.05 & 11.96 \\
\hline Number of primary branches /plant & 13.83 & 0.98 & 0.51 & 0.14 \\
\hline Number of secondary branches /plant & 25.36 & 17.28 & 46.43 & 24.25 \\
\hline Siliquae /plant & 22.31 & 8.73 & 15.33 & 7.04 \\
\hline Length of main shoot (cm) & 13.94 & 6.89 & 24.43 & 7.02 \\
\hline Siliquae on main shoot & 14.61 & 3.93 & 7.23 & 2.17 \\
\hline Siliqua length (cm) & 13.07 & 7.17 & 30.12 & 8.11 \\
\hline Seeds /siliqua & 17.88 & 11.45 & 41.04 & 15.12 \\
\hline 1000-seed weight (g) & 25.41 & 18.88 & 55.26 & 28.92 \\
\hline Seed yield /plant (g) & 25.57 & 19.97 & 61.04 & 32.15 \\
\hline Biological yield /plant (g) & 28.12 & 22.62 & 64.72 & 37.48 \\
\hline Harvest index (\%) & 27.62 & 20.91 & 57.34 & 32.62 \\
\hline & & & & \\
\hline
\end{tabular}


Table.4 Cluster composition in Brassica juncea following multivariate analysis in pooled over the environments

\begin{tabular}{|l|l|l|}
\hline $\begin{array}{l}\text { Cluster } \\
\text { number }\end{array}$ & $\begin{array}{c}\text { Number of } \\
\text { genotypes }\end{array}$ & \multicolumn{1}{|c|}{ Genotypes } \\
\hline I & 26 & $\begin{array}{l}\text { OMK-2-21, Varuna, OMK-2, OMK-3, RH-8544, OMK- } \\
5-2, \text { IC-355337, 03-143, Nav Gold, NRC-17, Zem-1, IC- } \\
355331, \text { RL-1359, OMK-5-1, NRC-2, RCC-4, Pusa } \\
\text { Jaikisan, Bawal-151, NRC-1, IC-355421, OMK-5-3, 03- } \\
218, \text { OMK-3-29, IC-355309, Vardan and OMK-5-4. }\end{array}$ \\
\hline II & & OMK-1 \\
\hline III & 1 & Geeta \\
\hline IV & 1 & 03-456 \\
\hline V & 1 & Heera \\
\hline VI & 1 & HPMM-03-108 \\
\hline
\end{tabular}

Table.5 Average intra- and inter-cluster distances in pooled over the environments

\begin{tabular}{|l|l|l|l|l|l|l|}
\hline Clusters & I & II & III & IV & V & VI \\
\hline I & $\mathbf{1 . 5 0}$ & 1.99 & 2.10 & 1.98 & 2.51 & 2.23 \\
& $\mathbf{( 1 . 2 2 )}$ & $(1.41)$ & $(1.45)$ & $(1.41)$ & $(1.58)$ & $(1.49)$ \\
\hline II & & $\mathbf{0 . 0 0}$ & 2.12 & 2.46 & 3.14 & 2.46 \\
& & $(\mathbf{0 . 0 0})$ & $(1.46)$ & $(1.57)$ & $(1.77)$ & $(1.57)$ \\
\hline III & & & $\mathbf{0 . 0 0}$ & 2.61 & 3.41 & 2.85 \\
& & & $(\mathbf{0 . 0 0})$ & $(1.62)$ & $(1.85)$ & $(1.68)$ \\
\hline IV & & & & $\mathbf{0 . 0 0}$ & 2.37 & 2.59 \\
& & & & $(\mathbf{0 . 0 0})$ & $(1.54)$ & $(1.61)$ \\
\hline V & & & & & $\mathbf{0 . 0 0}$ & 3.36 \\
& & & & & $(\mathbf{0 . 0 0})$ & $(1.83)$ \\
\hline VI & & & & & & $\mathbf{0 . 0 0}$ \\
& & & & & & $(\mathbf{0 . 0 0})$ \\
\hline
\end{tabular}

Values in bold figures are intra-cluster distances

Values in parenthesis are $\sqrt{ } \mathrm{D}^{2}=\mathrm{D}$ values 
Table.6 Cluster means for different characters in pooled over the environments

\begin{tabular}{|c|c|c|c|c|c|c|c|c|c|}
\hline $\begin{array}{ll}\text { Characters } & \text { Clusters }\end{array}$ & I & II & III & IV & V & VI & Mean & Minimum & Maximum \\
\hline CGR & 0.43 & 0.74 & 0.45 & 0.42 & 0.29 & 0.52 & 0.47 & 0.29 & 0.74 \\
\hline RGR & 0.03 & 0.03 & 0.03 & 0.03 & 0.03 & 0.03 & 0.03 & 0.03 & 0.03 \\
\hline NAR & 0.02 & 0.04 & 0.02 & 0.02 & 0.02 & 0.04 & 0.03 & 0.02 & 0.04 \\
\hline LAR & 1.15 & 0.93 & 1.14 & 1.60 & 1.30 & 1.13 & 1.21 & 0.93 & 1.60 \\
\hline LAI & 0.73 & 0.63 & 0.89 & 1.22 & 0.86 & 0.46 & 0.79 & 0.46 & 1.22 \\
\hline LAD & 27.76 & 24.50 & 34.39 & 48.26 & 33.04 & 18.23 & 31.03 & 18.23 & 48.26 \\
\hline SLW & 0.07 & 0.08 & 0.08 & 0.12 & 0.09 & 0.06 & 0.08 & 0.06 & 0.12 \\
\hline Days to flower initiation & 60.00 & 60.83 & 58.00 & 66.00 & 66.00 & 55.67 & 61.08 & 55.67 & 66.00 \\
\hline Days to $50 \%$ flowering & 70.17 & 69.17 & 70.00 & 74.83 & 78.33 & 73.50 & 72.67 & 69.17 & 78.33 \\
\hline Days to $75 \%$ maturity & 148.04 & 147.50 & 149.83 & 149.17 & 151.83 & 145.50 & 148.65 & 145.50 & 151.83 \\
\hline Plant height & 148.04 & 147.53 & 148.17 & 161.70 & 169.20 & 117.57 & 148.70 & 117.57 & 169.20 \\
\hline No. of primary branches / plant & 6.04 & 6.13 & 6.23 & 6.57 & 6.17 & 6.60 & 6.29 & 6.04 & 6.60 \\
\hline No. of secondary branches / plant & 17.83 & 15.97 & 18.50 & 18.50 & 20.77 & 17.43 & 18.17 & 15.97 & 20.77 \\
\hline Siliquae / plant & 228.67 & 259.83 & 220.97 & 222.30 & 264.47 & 241.80 & 239.67 & 220.97 & 264.47 \\
\hline Length of main shoot & 53.10 & 59.73 & 60.20 & 59.47 & 54.73 & 52.60 & 56.64 & 52.60 & 60.20 \\
\hline Siliquae on main shoot & 37.95 & 44.97 & 40.77 & 44.50 & 38.27 & 39.57 & 34.33 & 37.95 & 44.97 \\
\hline Siliqua length & 4.71 & 5.03 & 5.03 & 4.58 & 4.08 & 5.36 & 4.79 & 4.08 & 5.36 \\
\hline Seeds/ siliqua & 12.00 & 13.77 & 12.00 & 11.83 & 10.03 & 16.27 & 12.65 & 10.03 & 16.27 \\
\hline 1000- seed weight & 3.39 & 4.39 & 4.83 & 2.62 & 2.94 & 2.69 & 3.48 & 2.62 & 4.83 \\
\hline Seed yield / plant & 9.29 & 6.68 & 13.93 & 9.10 & 8.24 & 7.78 & 9.17 & 6.68 & 13.93 \\
\hline Biological yield / plant & 59.63 & 53.67 & 79.08 & 69.54 & 87.17 & 42.82 & 65.32 & 42.82 & 87.17 \\
\hline Harvest index & 16.02 & 12.10 & 16.91 & 13.25 & 9.39 & 18.67 & 14.39 & 9.39 & 18.67 \\
\hline
\end{tabular}


Table.7 Contribution of individual characters to the divergence among 31 genotypes of Brassica juncea in pooled over the environments

\begin{tabular}{|l|l|l|}
\hline Characters & Times ranked It & Contribution (\%) \\
\hline CGR & 55 & 11.83 \\
\hline RGR & 4 & 0.86 \\
\hline NAR & 1 & $0.22^{*}$ \\
\hline LAR & 3 & 0.65 \\
\hline LAI & 18 & 3.87 \\
\hline LAD & 5 & 1.08 \\
\hline SLW & 3 & 0.65 \\
\hline Days to flower initiation & 50 & 10.75 \\
\hline Days to 50 \% flowering & 6 & 1.29 \\
\hline Days to 75 \% maturity & 3 & 0.65 \\
\hline Plant height & 21 & 4.52 \\
\hline Number of primary branches / plant & 1 & $0.22 *$ \\
\hline Number of secondary branches/ plant & 36 & 7.74 \\
\hline Siliquae / plant & 13 & 2.80 \\
\hline Length of main shoot & 7 & 1.51 \\
\hline Siliquae on main shoot & 1 & $0.22 *$ \\
\hline Siliqua length & 53 & 11.40 \\
\hline Seeds/ siliqua & 17 & 3.66 \\
\hline 1000-seed weight & 61 & $13.12 * *$ \\
\hline Seed yield / plant & 53 & 11.40 \\
\hline Biological yield / plant & 20 & 7.31 \\
\hline Harvest index & 34 & \\
\hline Minm & & 4.30 \\
\hline
\end{tabular}

Minimum values; $\quad * *$ Maximum values 
The diversity in the present materials was also supported by the appreciable amount of variation among cluster means for different characters (Table 6). Based on the comparison of cluster means of different characters, it was observed that substantial differences existed among the cluster means for each character. The genotypes from cluster VI had shortest plant height along with earliest in days to flower initiation and 75 per cent maturity coupled with highest mean values for number of primary branches per plant, siliqua length, seeds per siliqua and harvest index. Cluster II had the genotypes with highest mean values for CGR, RGR, NAR and siliquae on main shoot along with earliest in days to 50 per cent flowering. Cluster III consisted of the genotypes with highest mean values for RGR, length of main shoot, 1000-seed weight and seed yield per plant. Likewise, cluster V had genotypes with highest mean values for number of secondary branches per plant, siliquae per plant and biological yield per plant.

The genotypes belonging to these clusters could be utilized in hybridization programme in order to get transgressive segregants for desirable characters. The relative contribution of different characters towards the expression of genetic divergence revealed that 1000-seed weight contributed maximum (13.1\%) towards genetic divergence followed (Table 7) by CGR (11.83\%), siliqua length (11.40 $\%)$ and seed yield per plant (11.40\%) among 31 genotypes under study.

In conclusion, the overall results indicated that a considerable diversity exists in the set of accessions analysed in this investigation. Considering the importance of diversity in germplasm improvement and that a greater combining ability is expected in crosses among genetically diverse parents, the genotype belonging to different groups identified during the present study will constitute promising parents for hybridization in Indian mustard improvement programme.

\section{References}

Anushree and Pandey A., 2017. Genetic divergence for thermotolerance based on physiological parameters during germination in Indian mustard (Brassica juncea (L.) Czern \& Coss.). Journal of Pharmacognosy and Phytochemistry, 6(5): 2775-2777.

Burton, G. and DeVane, E. H., 1953. Estimating heritability in tall fescue (Festuca arundinacea) from replicated clonal material. Agronomy Journal. 45(8): 478-481.

Chandra K., Anil Pandey, Mishra S. B., 2018. Genetic Diversity Analysis among Indian Mustard (Brassica juncea L. Czern \& Coss) Genotypes under Rainfed Condition. Int. J. Curr. Microbiol. App. Sci., 7(3): 256-268.

Gohel, K. and Mehta, D. R., 2014. Assessment of genetic diversity among mustard (Brassica juncea (L.) Czern \& coss) genotypes using PCR based DNA markers. International Journal of Applied and Pure Science and Agriculture, 1(1): 31-37.

Johnson, H. W., Robinson, H. F. and Comstock, R. E. 1955. Estimates of genetic and environmental variability in soybean. Agronomy Journal, 47(3): 314-318.

Kumar, B., Pandey, A. and Singh, S. K. 2013. Genetic Diversity for AgroMorphological and Oil Quality Traits In Indian Mustard (Brassica juncea L. Czern \& Coss). The Bioscan, 8 (3): 771-775.

Kumar, S. and Misra, M. N. 2007. Study on genetic variability, heritability and genetic advance in populations in Indian mustard [Brassica juncea L. Czern \& Coss.]. International Journal 
of Plant Sciences, 2 (1) 188-190.

Lodhi, B., Thakral, N. K., Avtar R., and Singh A., 2014. Genetic variability, association and path analysis in Indian mustard (Brassica juncea). Journal of oilseed Brassica, 5(1): 26-31.

Mahak Singh, Singh, H. L., Satyendra and Dixit, R. K. 2004. Studies on genetic variability, heritability, genetic advance and correlation in Indian mustard (Brassica juncea (L.) Czern. and Coss.). Plant Archives, 4(2): 291294.

Mahalanobis, P. C. 1936. On the generalized distance in statistics. In: Proceedings National Academy of Sciences, India 2: 49-55.

Mahla, H. R., Jambhulkar, S. J., Yadav, D. K. and Sharma, R. 2003. Genetic variability, correlation and path analysis in Indian mustard [Brassica juncea (L.) Czern and Coss.]. Indian Journal of Genetics and Plant Breeding, 63(2): 171-172.

Othmane, M. 2015. Genetic Variability in Glucosinolates in Seed of Brassica juncea: Interest in Mustard Condiment. Journal of Chemistry Volume 2015, Article ID 606142, 6 pages http://dx.doi.org/10.1155/ 2015/606142.

Panse, V. G. and Sukhatme, P. V. 1985. Statistical methods for agricultural workers. Indian Council of Agricultural Research, New Delhi. p 359.

Rao, C. R. 1952. Advance Statistical Methods in Biometrical Research. John Wiley and Sons Inc. New York Edn.1.

Satyendra, Kumar and Mishra, M. N. 2007. Study on genetic variability, heritability and genetic advance in $\mathrm{F}_{3}$ populations in Indian mustard. International Journal of Plant Sciences, Muzaffarnagar, 2(1): 188190.
Shekhawat, K., Rathore, S. S., Premi, O. P., Kandpal, B. K., and Chauhan, J. S. 2012. Advances in Agronomic Management of IndianMustard (Brassica juncea (L.) Czern. Coss): An Overview. International Journal of Agronomy: Volume 2012, Article ID 408284, 14 pages doi:10.1155/2012/408284.

Singh, D., Arya, R. K., Chandra, N., Niwas, R and Salisbury, P. 2010. Genetic diversity studies in relation to seed yield and its component traits in Indian mustard (Brassica juncea L. Czern \& Coss.). Journal of Oilseed Brassica, 1(1): 19-22.

Singh, M., Tomar, A., Mishra, C. N. and Srivastava, S.B.L. 2011. Genetic parameters and character association studies in Indian mustard. Journal of Oilseed Brassica, 2(1): 35-38.

Singh, V.V. Rai, P.K. Siddiqui, S.A. Verma V. and Rajbir Yadav. 2011. Genetic variability and relative drought tolerance in interspecific progenies of Brassica juncea. Agric. Biol. J. N. Am., 2(1): 34-41.

Srivastav, M. K. and Singh, R. P. 2000. Genetic divergence analysis in Indian mustard [Brassica juncea (L.) Czern \& Coss]. Crop Research Hisar, 20(3): 555-557.

Synrem, G. J. Rangare, N. R. Myrthong I. and Bahadure D.M.. 2014. Variability studies in Intra specific crosses of Indian mustard [Brassica juncea (L.) Czern and Coss.] genotypes. IOSR Journal of Agriculture and Veterinary Science, 7 (9): 29-32.

Tahira, R., Ihsan-Ullah and Saleem, M. 2013. Evaluation of genetic diversity of raya (Brassica juncea) through RAPD markers. Int. J. Agric. Biol., 15: 11631168.

USDA,. 2016. United States Department of Agriculture-Rapeseed area, yield and 
production Table No. 15. http: // www. fas. usda. gov / psd online / psd report. Asps (created on July 31, 2016).

Verma, M. M., Gill, K. S. and Virk, D. S. 1987. Genotype x Environment interaction, its measurement and significance in plant breeding. $P l$. Agric. Uni. pp: 3-10.

Verma, R., Sharma, R. and Sharma, S. K. 2008. Association studies among yield and its component characters in Indian mustard [Brassica juncea (L.) Czern \& Coss]. Plant Archives, 8(2): $963-$ 965.

Yadava, D. K., Giri S. C., Vignesh, M., Vasudev, S., Yadav, A. K., Dass, B., Singh, R., Singh, N., Mohapatra, T. and Prabhu, K. V. 2011. Genetic variability and trait association studies in Indian mustard (Brassica juncea). Indian Journal of Agricultural Science, 81(8): 712-716.

\section{How to cite this article:}

Arpna Kumari and Vedna Kumari. 2018. Genetic Variability and Divergence Studies for Seed Yield and Component Characters in Indian Mustard [Brassica juncea (1.) Czern. \& coss.]. Int.J.Curr.Microbiol.App.Sci. 7(07): 3376-3388. doi: https://doi.org/10.20546/ijcmas.2018.707.393 